Journal of Agrometeorology 23 (3) : 279-285 (September 2021)

\title{
Maize productivity analysis in response to climate change under different nitrogen management strategies
}

\author{
NISHANT K SINHA ${ }^{1 *}$, M. MOHANTY ${ }^{1}$, J. SOMASUNDARAM ${ }^{1}$, R. S. CHAUDHARY ${ }^{1}$, H. PATRA ${ }^{2}$, \\ K. M. HATI ${ }^{1}$, RANA PRATAP SINGH ${ }^{1}$, JYOTI KUMAR THAKUR ${ }^{1}$, JITENDRA KUMAR ${ }^{1}$, \\ DHIRAJ KUMAR ${ }^{1}$, ALKA RANI ${ }^{1}$, A. B. SINGH ${ }^{1}$, S. K. BAL ${ }^{3}$, K. SAMMI REDDY ${ }^{3}$ \\ and M. PRABHAKAR ${ }^{3}$ \\ ${ }^{1}$ ICAR-Indian Institute of Soil Science, Bhopal, India \\ ${ }^{2}$ CropData Technology (P) Ltd., Nagpur, India, ${ }^{3}$ ICAR-CRIDA, Hyderabad, India \\ Corresponding author : nishant.sinha76211@gmail.com
}

\begin{abstract}
The evaluation of climatic change impact on maize grain and biomass yield under different $\mathrm{N}$ management practices through a well-calibrated and validated APSIM model in Vertisol of central India has been made. Climate scenarios were derived from seven global climate models (GCM) for two representative concentration pathways (RCPs), i.e. RCP4.5 and RCP8.5, and two-time slices, i.e. 2050 and 2080. The five $\mathrm{N}$ scenarios, namely N0\%, N50\%, N100\%, N150\%, and 100\% organic, were studied in different climatic scenarios. The probability of exceedance showed that N0\%, N50\%, N100\%, N150\%, and 100\% organic treatments have a $50 \%$ chance of yield greater than 1.0, 3.40, 4.20, 4.45 and $3.84 \mathrm{t} \mathrm{ha}^{-1}$, respectively. The average reduction of maize yield was $-44.4,-20,-19.7-17.9$ and 22.5 per cent in $\mathrm{N} 0 \%, \mathrm{~N} 50 \%, \mathrm{~N} 100 \%$, $\mathrm{N} 150 \%, 100 \%$ organic, respectively under RCP4.5 over the baseline period (1980-2010). For RCP8.5, the average reduction of maize yield in N $0 \%, N 50 \%, N 100 \%, N 150 \%, 100 \%$ organic was 41.2, 21.2, 20.8 20.6 and 23.1 per cent, respectively. Simulation results suggested that a higher decrease of maize yield in 100 per cent organic treatments than inorganic treatments is due to variability in $\mathrm{N}$ uptake.
\end{abstract}

Key words: Maize, nitrogen management, modelling, climate change, APSIM

The evidence of climate change is ubiquitous with an increase in temperature and $\mathrm{CO}_{2}$ concentration, changing precipitation patterns, increased number and severity of climate-related natural disasters, such as heat waves, droughts, severe storms, cyclones, and flooding (Anonymous, 2020). Since agriculture is heavily dependent on weather and climate, the climate extremes may interrupt crop growth, irrigation patterns, water use efficiency, soil health, and its biodiversity, which leads to a reduction in food production and thus, poses threats to food security. The global mean temperature has increased by $0.8^{\circ} \mathrm{C}$ since $1850 \mathrm{~s}$. It is projected to increase by 2 to $7^{\circ} \mathrm{C}$ at the end of the century (Allison et al., 2009). The atmosphere's $\mathrm{CO}_{2}$ concentration has risen from 284 to 412 ppm from 1832 to 2020. The $\mathrm{CO}_{2}$ is expected to increase to $798 \mathrm{ppm}$ by the end of the century (Tans and Keeling, 2014). The rising temperature and $\mathrm{CO}_{2}$ concentration could significantly affect crop production in different regions of the world.
Globally, the range of yield changes under different climatic scenarios for wheat, rice, maize, and soybean are -6.9 to -22.4 per cent, -3.3 to -10.8 per cent, -8.6 to -27.8 per cent, and -3.6 to -11.6 per cent, respectively. On average, $1.0^{\circ} \mathrm{C}$ increase in global mean temperature would reduce global production of wheat by 6.0, rice by 3.2, and maize by 7.4 and soybean by 3.1 per cent (Zhao et al., 2017).

Maize is one of the commonly grown grain crops and remains a source of staple food and food security for most developing countries (Mohanty et al., 2017). Recently, India has seen a substantial jump in maize production and became the seventh-largest maize producer country with $27.82 \mathrm{mt}$ production and net exporter with $1.06 \mathrm{mt}$ during 2018 (FAOSTAT, 2020). Maize is an exhaustive nutrient crop; therefore, its grain yield and biomass are largely varied with different nitrogen rates. Nitrogen (N) fertilizer plays a vital role in optimizing the trade-off between grain yield and profit 
(Jin et al., 2012). Hence, effective nitrogen fertilization management is a leading challenge for enhancing maize productivity and environmental sustainability (Ma et al., 2006). The addition of $\mathrm{N}$ in agricultural soil alters the fluxes of greenhouse gases (GHGs). Moreover, $\mathrm{N}$ usually increases net primary productivity with more $\mathrm{CO}_{2}$ fixation in terrestrial systems and enhances carbon sequestration in soil due to more litter production (Fagodiya et al., 2017). Nonetheless, the use of models in practical applications to assist in real-life challenges such as $\mathrm{N}$ rate guidance under different agro-ecosystems is limited (Puntel et al., 2016). However, dynamic cropping system simulation models such as Agricultural Production Systems sIMulator (APSIM), Decision Support System for Agrotechnology Transfer (DSSAT), CropSyst, and others have been used to investigate nutrient-crop-weather dynamics. With the help of simulation models, it is practically possible to estimate the long-term application of nutrient management practices on crop productivity, soil organic carbon (SOC) sequestration and climate change impact studies (Mohanty et al., 2020). Therefore, the present study aims to evaluate the APSIM-maize module in simulating the pattern of maize grain yield, biomass, and $\mathrm{N}$ uptake under different long term $\mathrm{N}$ management scenarios for present and future climates.

\section{MATERIALS AND METHODS}

\section{Experimental details}

The field experiment was carried out at the research farm of ICAR-India Institute of Soil Science, Bhopal $\left(23.28^{\circ} \mathrm{N}, 77.48{ }^{\circ} \mathrm{E}\right)$ on Vertisol. The study site's climate is hot sub-humid with annual mean air temperature, mean annual rainfall, and annual potential evapotranspiration of $25^{\circ} \mathrm{C}, 1169 \mathrm{~mm}$ and $1400 \mathrm{~mm}$, respectively. The soil of the experimental site is classified as a deep clayey (Isohyperthermic Typic Haplustert) with 58 per cent clay, 22 per cent silt, and 20 per cent sand in surface soil $(0-15 \mathrm{~cm})$. The experiment was initiated in 2011 with four nitrogen (N) levels (N0\%, N50\%, N100\%, and $\mathrm{N} 150 \%$ of the recommended dose of fertilizers) in maize (cv KH-101). The treatments N0\%, N50\%, N100\% and N150\% contain 0, 60, 120 and $180 \mathrm{Kg} \mathrm{N} \mathrm{ha}^{-1}$, respectively. The phosphorous and potassium are equally applied in all the treatments at the rates of $60 \mathrm{~kg} \mathrm{P}_{2} \mathrm{O}_{5} \mathrm{ha}^{-1}$ and $40 \mathrm{~kg} \mathrm{~K}_{2} \mathrm{O} \mathrm{ha}^{-1}$, respectively.

\section{Climatic Scenarios}

The IPCC fifth assessment report used four scenarios, namely RCP2.6, RCP4.5, RCP6.0, and RCP8.5, to facilitate future climate change assessment for the year 1980 to 2100 . The study showed that changes in $\mathrm{CO}_{2}$, temperature, precipitation could cover both medium and extreme scenarios. Therefore, the wellreasoned RCP4.5 and RCP8.5 were selected to conduct potential climate change impact simulations because they cover both medium and extreme scenarios. In this study, seven global climate models (GCMs) named BCCCSM1-1, BCC-CSM1-1-M, GFDL-CM3, GFDL-ESM2G, GFDL-ESM2M, GISS-E2-H, and GISS-E2-R were used to generate future climate data (2010-2095) for the Bhopal station, under scenarios RCP4.5 and RCP8.5. The future data were extracted through the MarkSim web version for IPCC AR5 data (http://gismap.ciat.cgiar.org/ MarkSimGCM/).

The APSIM Modeling Platform: Calibration, validation, and crop management practices

In this study, a well-calibrated APSIM-maize model (v 7.10) was used to simulate maize yield, biomass, and $\mathrm{N}$ uptake in different $\mathrm{N}$ management and climate scenarios. The crop coefficient for the maize cultivar $\mathrm{KH}-$ 101 was set as per Mohanty et al. (2017). However, the model was re-validated with the multiyear data of maize grain and biomass yield under different $\mathrm{N}$ application rates. The model validation was performed for 2017 and 2018 maize yield and biomass under the treatments N0\%, N50\%, N100\%, and N150\%.Three statistical criteria, such as root mean square error (RMSE), coefficient of determination $\left(\mathrm{R}^{2}\right)$, and Nash-Sutcliffe efficiency (NSE), were calculated to measure the degree of coincidence between observed and simulated grain and biomass yield. The computational forms of the statistical criteria used are given below:

\section{Root mean square error $(\mathrm{RMSE})=$}

$$
\sqrt{\frac{\sum_{i=1}^{N}\left(O_{i-} P_{i}\right)^{2}}{N}}
$$

Coefficient of determination $\left(R^{2}\right)=$

$$
\left[\frac{N\left(\sum O P\right)-\left(\sum O\right)-\left(\sum P\right)}{\sqrt{\left[N \sum 0^{2}-\left(\sum 0\right)^{2}\right]\left[N \sum P^{2}-\left(\sum P\right)^{2}\right]}}\right]^{2}
$$


Table 1: Climate variables under different climatic scenarios at Bhopal, Madhya Pradesh.

\begin{tabular}{ccccccccccc}
\hline Scenarios & Year & $\begin{array}{l}\text { SRAD } \\
\left(\mathrm{MJ} \mathrm{m}^{-2}\right. \\
\left.\text { day }^{-1}\right)\end{array}$ & $\begin{array}{l}\mathrm{T}_{\max } \\
\left({ }^{\circ} \mathrm{C}\right)\end{array}$ & $\begin{array}{l}\mathrm{T}_{\min } \\
\left({ }^{\circ} \mathrm{C}\right)\end{array}$ & $\begin{array}{l}\mathrm{T}_{\text {avg }} \\
\left({ }^{\circ} \mathrm{C}\right)\end{array}$ & $\begin{array}{l}\text { Change } \\
\text { in } \mathrm{T}_{\text {avg }} \\
\left({ }^{\circ} \mathrm{C}\right) \text { over } \\
\text { baseline }\end{array}$ & $\begin{array}{l}\mathrm{CO}_{2} \\
(\mathrm{ppm})\end{array}$ & $\begin{array}{l}\text { Change } \\
(\%) \text { over } \\
\text { baseline }\end{array}$ & $\begin{array}{l}\text { Rainfall } \\
(\mathrm{mm})\end{array}$ & $\begin{array}{l}\text { Change } \\
(\%) \text { over } \\
\text { baseline }\end{array}$ \\
\hline Baseline & $1976-2005$ & 22.7 & 32.0 & 18.4 & 25.2 & & 354 & & 1169 & \\
& $2050 \mathrm{~s}$ & 19.1 & 33.8 & 20.5 & 27.2 & 2.0 & 495 & 40.7 & 1228 & 5 \\
RCP4.5 & $2080 \mathrm{~s}$ & 19.1 & 34.3 & 21.1 & 27.7 & 2.5 & 532 & 36.6 & 1271 & 8 \\
& $2050 \mathrm{~s}$ & 19.1 & 34.3 & 21.3 & 27.8 & 2.6 & 572 & 41.5 & 1271 & 8 \\
RCP8.5 & 2080s & 19.1 & 36.0 & 23.3 & 29.7 & 4.5 & 798 & 78.1 & 1352 & 14 \\
\hline
\end{tabular}

Nash-Sutcliffe efficiency (NSE) $=$

$$
1-\frac{\sum_{i=1}^{n}\left(o_{i}-p_{i}\right)^{2}}{\sum_{i=1}^{n}\left(o_{i}-\bar{o}\right)^{2}}
$$

Where, ' $\mathrm{N}$ ' is the number of points; ' $\mathrm{P}$ 'is predicted values; ' $\mathrm{O}$ ' is the observed values; ' $\overline{\mathrm{O}}$ ' is the mean of observed yield

Further, the model was instructed to sow maize between 15 June to 10 July based on $30 \mathrm{~mm}$ of rainfall criteria in three consecutive days and $200 \mathrm{~mm}$ of minimum allowable soil water. The nitrogenous fertilizer was applied as urea nitrogen in three splits. The first dose was applied during sowing, and the second and third doses were administered after 25 and 50 days of sowing. The five $\mathrm{N}$ scenarios, such as N0\%, N50\%, N100\%, N150\%, and $100 \%$ organic, were simulated for RCPs 4.5 and 8.5 in different time slices, i.e., 2050 and 2080. In 100\% organic treatment, 12 tonnes of farmyard (FYM) were added annually on $30^{\text {th }}$ May of each year. On an average, FYM contained 25 per cent C, 0.95 per cent N, 0.55 per cent $\mathrm{P}$, and 0.71 per cent $\mathrm{K}$ on a dry weight basis.

\section{RESULTS AND DISCUSSION}

\section{Climate change under future scenarios}

The comparison of historical and projected climate normal (temperature, precipitation, and solar radiation) and $\mathrm{CO}_{2}$ concentration at the study site has been shown in Table 1. Compared to the baseline scenario (19802010), the projected changes for annual precipitation under RCP4.5 (2050s), RCP4.5 (2080s), RCP8.5 (2050s), and RCP8.5 (2080s) scenarios increased by 5.0, 8.0, 8.0, and 14.0 per cent, respectively (Table 1). However, an increase in projected average temperature $\left(\mathrm{T}_{\text {avg }}\right)$ under
RCP4.5 (2050s), RCP4.5 (2080s), RCP8.5 (2050s), and RCP8.5 (2080s) was reported by $2.0,2.5,2.6$, and $4.5^{\circ} \mathrm{C}$, respectively. The annual maximum temperature $\left(\mathrm{T}_{\max }\right)$ increase was $1.8^{\circ} \mathrm{C}$ in the $2050 \mathrm{~s}$, and $2.3^{\circ} \mathrm{C}$ in the $2080 \mathrm{~s}$ under RCP4.5; $2.3^{\circ} \mathrm{C}$ in $2050 \mathrm{~s}$ and $4.0^{\circ} \mathrm{C}$ in the $2080 \mathrm{~s}$ under RCP8.5 compared to baseline. Similarly, the annual minimum temperature $\left(\mathrm{T}_{\text {min }}\right)$ increase was $2.1^{\circ} \mathrm{C}$ in the 2050s and $2.7^{\circ} \mathrm{C}$ in the 2080s under RCP4.5; $2.9^{\circ} \mathrm{C}$ in $2050 \mathrm{~s}$ and $4.9^{\circ} \mathrm{C}$ in the 2080s under RCP8.5 compared to baseline. The average $\mathrm{CO}_{2}$ concentrations increased to 495, 532, 572, and 798 ppm for RCP4.5 (2050s), RCP4.5 (2080s), RCP8.5 (2050s), and RCP8.5 (2080s) scenarios, respectively (Table 1 ).

\section{APSIM validation}

Overall, the APSIM simulation satisfactorily predicted the observed maize grain and biomass yield under the different $\mathrm{N}$ management practices. The RMSE, $\mathrm{R}^{2}$, and NSE values for maize grain yield were $0.8 \mathrm{t}$ ha ${ }^{1}, 0.82$, and 0.71 , respectively. For the maize biomass, RMSE, $\mathrm{R}^{2}$, and NSE values were $1.1 \mathrm{t} \mathrm{ha}^{-1}, 0.83$, and 0.86 , respectively. The NSE is a widely used and potentially reliable statistic for assessing the goodness of fit of models. Moriasi et al. (2007) used the NSE value to classify the simulation results into unsatisfactory (NSE $<0.5)$, satisfactory $(0.5<\mathrm{NSE}<0.65)$, good $(0.65$ $<\mathrm{NSE}<0.75)$, and very good $(0.75<\mathrm{NSE}<1)$. Moreover, when NSE is greater than 0.5 and the $\mathrm{R}^{2}$ is greater than 0.6 , it is suggested that the model's simulation results are acceptable (Lin et al., 2017). Based on NSE and $\mathrm{R}^{2}$ value obtained in this study, we could say that validation results were in good agreement between the observed and simulated maize and biomass yield. The average model maize yield was reported 6 per cent lower, while biomass was reported 2 per cent higher than observed data. 
Table 2: Maize grain and biomass yield under different nitrogen management strategies in response to climate change

\begin{tabular}{lcccccccccccc}
\hline \multicolumn{1}{c}{ Scenarios } & Year & \multicolumn{4}{c}{ Grain yield $\left(\mathrm{t} \mathrm{ha}^{-1}\right)$} & \multicolumn{6}{c}{ Biomass yield $\left(\mathrm{t} \mathrm{ha}^{-1}\right)$} \\
\cline { 2 - 11 } & & $\begin{array}{c}100 \% \\
\text { Organic }\end{array}$ & $150 \% \mathrm{~N}$ & $100 \% \mathrm{~N}$ & $50 \% \mathrm{~N}$ & $0 \% \mathrm{~N}$ & $\begin{array}{c}100 \% \\
\text { Organic }\end{array}$ & $\begin{array}{c}150 \% \\
\mathrm{~N}\end{array}$ & $100 \% \mathrm{~N}$ & $50 \% \mathrm{~N}$ & $0 \% \mathrm{~N}$ \\
\hline Base & 3.9 & 4.5 & 4.1 & 3.4 & 1.1 & 8.5 & 9.1 & 8.8 & 8.0 & 3.3 \\
$(1980-2010)$ & & & & & & & & & & & \\
RCP4.5 & 2050 & 3.0 & 3.7 & 3.4 & 2.7 & 0.6 & 7.1 & 7.9 & 7.5 & 6.8 & 2.6 \\
& & $(-21.8)$ & $(-16.6)$ & $(-18.8)$ & $(-19.1)$ & $(-48.5)$ & $(-15.9)$ & $(-14.0)$ & $(-15.2)$ & $(-14.9)$ & $(-21.5)$ \\
& 2080 & 3.0 & 3.6 & 3.3 & 2.7 & 0.6 & 7.0 & 7.7 & 7.4 & 6.7 & 2.6 \\
& & $(-23.2)$ & $(-19.1)$ & $(20.6)$ & $(-20.8)$ & $(-40.3)$ & $(-16.9)$ & $(-15.5)$ & $(-16.3)$ & $(-15.9)$ & $(-19.4)$ \\
RCP8.5 & 2050 & 3.0 & 3.7 & 3.3 & 2.7 & 0.6 & 7.1 & 7.8 & 7.4 & 6.7 & 2.6 \\
& $(-22.3)$ & $(-17.4)$ & $(-19.6)$ & $(-20.3)$ & $(-40.2)$ & $(-16.6)$ & $(-14.7)$ & $(-15.8)$ & $(-15.8)$ & $(-21.3)$ \\
& 2080 & 2.9 & 3.4 & 3.2 & 2.6 & 0.6 & 7.0 & 7.5 & 7.3 & 6.6 & 2.5 \\
& $(-23.8)$ & $(-23.9)$ & $(-21.9)$ & $(-22.2)$ & $(-40.2)$ & $(-17.7)$ & $(-18.3)$ & $(-17.2)$ & $(-16.9)$ & $(-22.5)$ \\
\hline
\end{tabular}

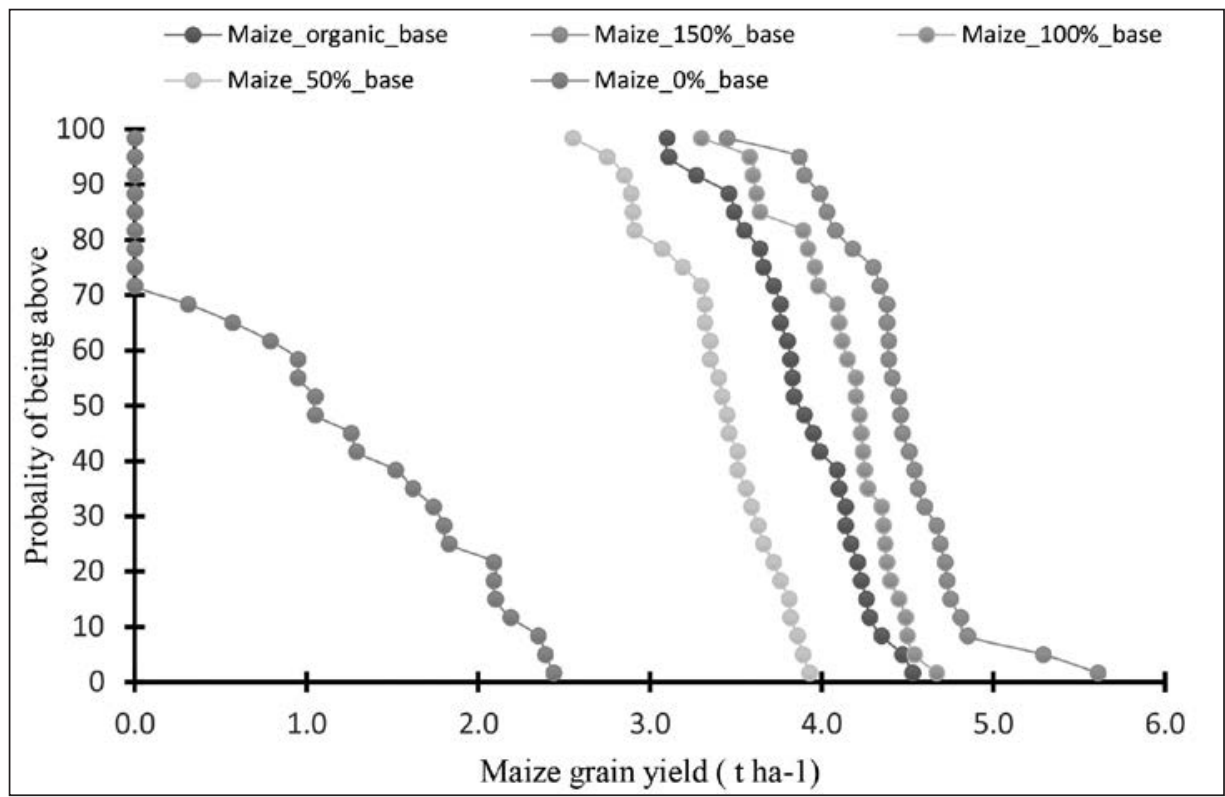

Fig. 1: Probability of exceedance of maize yield based on 30 years of weather data for different nitrogen management strategies

\section{Baseline yield risk assessment}

The probability of exceedance graph for different $\mathrm{N}$ management strategies has been shown in Fig. 1. The probability of exceedance is widely used as a statistical metric describing the probability that a particular value will be met or exceeded. Fig. 1 indicates that maize yield under different $\mathrm{N}$ management scenarios differs substantially. The N0, N50, N100, N150 and 100 per cent organic treatments have 50 per cent chance of yield greater than 1.0, 3.40, 4.20, 4.45 and $3.84 \mathrm{t} \mathrm{ha}^{-1}$, respectively. Alternatively, during 30 years of simulation, yield less than 1.0, 3.40, 4.20, 4.45, and $3.84 \mathrm{t} \mathrm{ha}^{-1}$ in N0, N50, N100, N150, and 100 per cent organic treatments, respectively, would be expected for 15 years. Over the 30 years of periods, the maximum yield obtained under N0, N50, N100, N150, and 100 per cent organic treatments was $2.44,3.93,4.67,5.6$ and $4.53 \mathrm{t} \mathrm{ha}^{-1}$, respectively.

In general, maize yield increased with a corresponding increase in soil $\mathrm{N}$ at higher $\mathrm{N}$ fertilizer rates. The higher maize yield with increasing soil $\mathrm{N}$ is attributed to the soil nutrients dynamics initiated by optimal soil N-P balance and essential plant metabolic pathways. Nitrogen plays a vital role in photosynthesis and is an integral part of the protein. It is necessary for enzymatic biochemical and physiological reactions in plant metabolism. Nitrogen is mainly responsible for increasing photosynthesizing area and thus influences plant growth and productivity to a greater extent (Mehta 


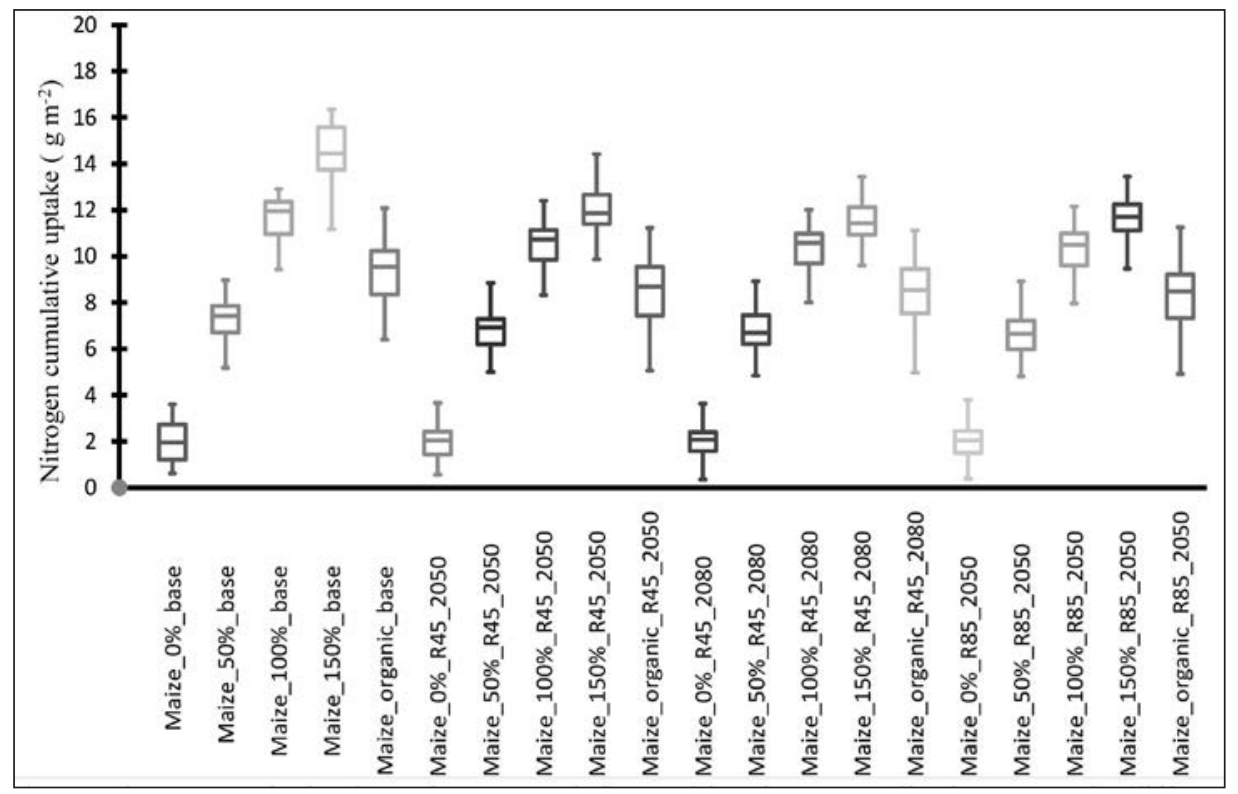

Fig. 2: Nitrogen uptake by the maize crop as influenced by nitrogen application rate under different climate change scenarios

et al., 2011). The results, i.e., higher maize yield under higher $\mathrm{N}$ application rates, are consistent with the finding of Srivastava et al. (2018).

The average yield under 100 per cent $\mathrm{N}$ and 100 per cent organic treatments was 4.14 and $3.90 \mathrm{t}$ $\mathrm{ha}^{-1}$, respectively. The lower average yield under the organic treatments may be due to lower plant-available $\mathrm{N}$ in commonly used organic fertilizers such as manure, compost, green manure, organic wastes and slow nitrogen mineralization, especially during early crop establishment stages (Mohanty et al., 2016). The release of nitrogen from the organic materials is positively correlated with its initial quality. It has been seen that net nitrogen mineralization occurs if the nitrogen concentration is above 2 per cent, and immobilization occurs below that concentration (Mohanty et al., 2013). However, organic treatments perform well in other sustainability domains such as soil health, animal welfare, and farm profitability.

\section{Climate change impacts on maize grain yield and biomass}

The results of climate change impact on maize grain and biomass yield are summarized in Table 2 . Compared to the baseline scenarios, the maize grain yield decreased by $-21.8,-23.2,-22.3$ and -23.8 per cent under RCP4.5 (2050s), RCP4.5 (2080s), RCP8.5 (2050s) and RCP8.5 (2080s), respectively in 100 per cent organic treatments. The biomass yield reduction simulated in organic treatment was $-15.9,-16.9,-16.6$, and -17.7 per cent for RCP 4.5 (2050s), RCP 4.5 (2080s), RCP 8.5 (2050s) and RCP 8.5 (2080s), respectively. For the 0 per cent $\mathrm{N}$, under different RCPs, a decrease in maize grain and biomass yield ranged from -16.6 to -23.9 per cent and -21.5 to -22.5 per cent, respectively, compared to baseline. For the 50 per cent $\mathrm{N}$, the maize grain yield was decreased by $-19.1,-20.8,-20.3$ and -22.2 per cent, while maize biomass yield was reduced by $-14.9,-15.9,-15.8$ and -16.9 per cent under RCP4.5 (2050s), RCP4.5 (2080s), RCP8.5 (2050s) and RCP8.5 (2080s), respectively, compared to the baseline scenario. Similarly, the decrease in maize grain and biomass yield for 100 per cent $\mathrm{N}$ treatment varied between -18.8 to -21.9 and -15.2 to -17.2 per cent, respectively. However, for 150 per cent $\mathrm{N}$, the decline in maize grain and biomass yield was observed to be between -16.6 to -23.9 per cent and -14.0 to -17.7 per cent, respectively. It is observed that decrease in yield parameters followed the trends: N0\% $>100 \%$ organic $>\mathrm{N} 50 \%,>\mathrm{N} 100 \%,>\mathrm{N} 150 \%$ under different climatic scenarios. A higher yield decrease in 100 per cent organic treatment than inorganic treatments can be explained by the variability (coefficient of variation) observed in $\mathrm{N}$ uptake in different $\mathrm{N}$ management practices under future climatic scenarios (Figure 2.). Schrama et al. (2018) reported that a $21 \%$ yield difference between organic and conventional systems was due to the variation in $\mathrm{N}$ uptake in the system. The variability in $\mathrm{N}$ uptake during the maize growth followed the trend similar to the decrease in maize yield under different $\mathrm{N}$ management practices 
i.e N0\% >100\% organic >N50\%, >N100\%, >N150\%. The average variability observed in N0\%, 100\% organic, N50\%, N100\%, N150\% was 45, 22, 16,9 and 9 per cent, respectively. The higher temperatures also resulted in lower $\mathrm{N}$ uptake and other key nutrients irrespective of the treatments (Craine et al., 2018).

On an average, within the treatment, a higher decrease was reported in RCP 8.5 and 2080s time slice than RCP4.5 and 2050s. It may be ascribed to a higher temperature during the maize crop cycles in RCP8.5 and 2080 time frames than the base and RCP4.5. The temperature increase in RCP4.5 (2080s) and RCP8.5 (2080s) was $2.5^{\circ} \mathrm{C}$ and $4.5^{\circ} \mathrm{C}$, compared to the baseline. However, at the same time, higher $\mathrm{CO}_{2}$ concentration was reported in the respective RCPs and time slices than in baseline (Table 1). Higher $\mathrm{CO}_{2}$ concentration may lead to higher crop yield (Patidar et al., 2020). However, the positive effect of $\mathrm{CO}_{2}$ fertilization is masked by the increase in temperature (Parry et al., 2004). In line with this study's finding, Ozturk et al. (2018) reported a shortening of the maize growing period and less $\mathrm{N}$ uptake under the high-temperature scenarios.

\section{CONCLUSIONS}

The results from this study indicated that there was a considerable reduction in maize grain and biomass yield under future climate change scenarios. The reduction was more in RCP8.5 compared to RCPs4.5. Furthermore, the yield reduction was more in 2080s times slices compared to 2050s. The decrease in maize grain and biomass yield was higher in 100 per cent organic than inorganic treatments, possibly due to higher variability in nitrogen uptake in organic treatment than inorganic treatments. From this simulation study, it was also observed that the $\mathrm{CO}_{2}$ fertilization effect was masked by the increase in temperature under different climate scenarios on maize grain and biomass yield.

\section{ACKNOWLEDGMENTS}

Authors sincerely thank ICAR-National Innovation in Climate Resilient Agriculture (NICRA) for funding this study.

Conflict of Interest Statement : The author(s)declare(s) that there is no conflict of interest.

Disclaimer : The contents, opinions, and views expressed in the research article published in the Journal of
Agrometeorology are the views of the authors and do not necessarily reflect the views of the organizations they belong to.

Publisher's Note : The periodical remains neutral with regard to jurisdictional claims in published maps and institutional affiliations.

\section{REFERENCES}

Anonymous 2020. https://science2017.globalchange.gov/ chapter/4/

Allison, I.; Bindoff, N.L.; Bindschadler, R.A.; Cox, P.M.; de Noblet, N.; England, M.H.; Francis, J.E.; Gruber, N.; Haywood, A.M.; Karoly, D.J.; Kaser, G.; Le Quéré, C.; Lenton, T.M.; Mann, M.E.; McNeil, B.I.; Pitman, A.J.; Rahmstorf, S.; Rignot, E.; Schellnhuber, H.J.; Schneider, S.H.; Sherwood, S.C.; Somerville, R.C.J.; Steffen, K.; Steig, E.J.; Visbeck, M.; Weaver, A.J., (2009). The Copenhagen Diagnosis, 2009: Updating the World on the Latest Climate Science. The University of New South Wales Climate Change Research Centre (CCRC), Sydney.

Craine, J.M., Elmore, A.J., Wang, L., Aranibar, J., Bauters, M., Boeckx, P., Crowley, B.E., Dawes, M.A., Delzon, S., Fajardo, A. and Fang, Y. (2018). Isotopic evidence for oligotrophication of terrestrial ecosystems. Nat. Eco. Evol., 2(11): 1735-1744.

Fagodiya, R.K., Pathak, H., Kumar, A., Bhatia, A. and Jain, N. (2017). Global temperature change potential of nitrogen use in agriculture: A 50 year assessment. Sci. Rep., 7 : 44928.

FAOSTAT. (2020). Faostat dataset. Retrieved fromhttp:// www.fao.org/faostat/

Jin, L., Cui, H., Li, B., Zhang, J., Dong, S. and Liu, P. (2012). Effects of integrated agronomic management practices on yield and nitrogen efficiency of summer maize in North China. Field Crops Res., 134 : 30-35.

Lin, F., Chen, X., and Yao, H. (2017). Evaluating the use of Nash-Sutcliffe efficiency coefficient in goodness-of-fit measures for daily runoff simulation with SWAT. J. Hydrol. Engg, 22(11) : 05017023. 
Ma, B.L., Subedi, K.D. and Liu, A. (2006). Variations in grain nitrogen removal associated with management practices in maize production. Nutr. Cyc. Agroecosys., 76(1): 6780

Mehta, S., Bedi, S., and Vashist, K. K. (2011). Performance of winter maize (Zea mays) hybrids to planting methods and nitrogen levels. Indian J. Agril. Sci., 81(1): 50-54.

Mohanty, M., Sinha, N.K., Reddy, K.S., Chaudhary, R.S., Rao, A.S., Dalal, R.C. and Menzies, N.W. (2013). How important is the quality of organic amendments in relation to mineral $\mathrm{N}$ availability in soils?. Agril. Res., 2(2): 99-110.

Mohanty, M., Sinha, N.K., Hati, K.M., Reddy, K.S. and Chaudhary, R.S. (2015). Elevated temperature and carbon dioxide concentration effects on wheat productivity in Madhya Pradesh: a simulation study. J. Agrometeorol., 17(2): 185189.

Mohanty, M., Reddy, K.S., Probert, M.E., Dalal, R.C., Sinha, N.K., Rao, A.S. and Menzies, N.W. (2016). Efficient nitrogen and water management for the soybean-wheat system of Madhya Pradesh, Central India assessed using APSIM model. Proc. Nat. Acad. Sci., India Sec. B: Biol. Sci., 86(1): 217-228.

Mohanty, M., Sinha, N.K., Patidar, R.K., Somasundaram, J., Chaudhary, R.S., Hati, K.M., Reddy, K.S., Prabhakar, M. and RAO, S. (2017). Assessment of maize (Zea mays L.) productivity and yield gap analysis using simulation modelling in subtropical climate of central India. $J$. Agrometeorol., 19(4), 343-346.

Mohanty, M., Sinha, N.K., Somasundaram, J., McDermid, S.S., Patra, A.K., Singh, M., Dwivedi, A.K., Reddy, K.S., Rao, C.S., Prabhakar, M. and Hati, K.M. (2020). Soil carbon sequestration potential in a Vertisol in central India-results from a 43-year long-term experiment and APSIM modeling. Agril. Sys., 184, p.102906.

Moriasi, D. N., Arnold, J. G., Van Liew, M. W., Binger, R. L., Harmel, R. D., and Veith, T. L. (2007). Model evaluation guidelines for systematic quantification of accuracy in watershed simulations. Trans. ASABE, 50(3), 885-900.

Ozturk, I., Kristensen, I. S., and Baby, S. (2018). Sensitivity of silage-maize to climate change in Denmark: A productivity analysis using impact response surface. European J. Agron., 98: 5564.

Parry, M. L., Rosenzweig, C., Iglesias, A., Livermore, M., and Fischer, G. (2004). Effects of climate change on global food production under SRES emissions and socio-economic scenarios. Global Environ. Change, 14(1): 53-67.

Patidar, R., Mohanty, M., Sinha, N.K., Gupta, S.C., Somasundaram, J., Chaudhary, R.S., Soliya, R., Hati, K.M., Prabhakar, M., Reddy, K.S. and Patra, A.K. (2020). Potential impact of future climate change on maize (Zea mays L.) under rainfed condition in central India. $J$. Agrometeorol., 22(1):18-23.

Puntel, L.A., Sawyer, J.E., Barker, D.W., Dietzel, R., Poffenbarger, H., Castellano, M.J., Moore, K.J., Thorburn, P. and Archontoulis, S.V. (2016). Modeling long-term corn yield response to nitrogen rate and crop rotation. Front. Plant Sci., 7, 1630.

Schrama, M., De Haan, J. J., Kroonen, M., Verstegen, H., and Van der Putten, W. H. (2018). Crop yield gap and stability in organic and conventional farming systems. Agric., Ecosyst. Environ., 256: 123-130.

Srivastava, R. K., Panda, R. K., Chakraborty, A., and Halder, D. (2018). Enhancing grain yield, biomass and nitrogen use efficiency of maize by varying sowing dates and nitrogen rate under rainfed and irrigated conditions. Field Crops Res., 221, 339-349.

Tans, P. and Keeling, R. (2014). Trends in atmospheric carbon dioxide. NOAA ESRL Global Mon. Div.,

Zhao, C., Liu, B., Piao, S., Wang, X., Lobell, D.B., Huang, Y., Huang, M., Yao, Y., Bassu, S., Ciais, P. and Durand, J.L. (2017). Temperature increase reduces global yields of major crops in four independent estimates. Proc. National Acad. Sci., 114(35): 9326-9331. 